\title{
A kultúra területi mérhetősége és a kistérségek közművelődési jellemzői
}

\section{The regional measurability of culture and the traits of community culture}

\author{
FÁBIÁN ATTILA, TÓTH BALÁZS ISTVÁN
}

KULCSSZAVAK: kultúra, közművelődés, kulturális gazdaság, faktoranalízis, klaszteranalízis, fejlettség

ABSZTRAKT: A kultúra gazdasági szerepének elemzése és területfejlesztéssel való viszonyának értelmezése egyre nagyobb jelentőséggel bír napjainkban. A tanulmány a kultúra és kultúraelemzés néhány regionális vonatkozásának bemutatását követően arra a kérdésre keresi a választ, hogy miként számszerüsíthető a kultúra, valamint miként ragadható meg annak térszerkezeti hatása. Ami mérhető - vagyis amire elérhető statisztikai adatok léteznek - az valóban a kultúra teljes spektrumát öleli-e fel, avagy csak néhány szegmensre koncentrálnak az „adatbányászok”, miközben számos értékes információ rejtve marad. A dolgozatban a kulturális gazdaság közművelődési alrendszerét előtérbe helyezve empirikus elemzést is közlünk a hazai kistérségekre vonatkozóan. A hazai kistérségek közművelődési helyzetét többváltozós statisztikai módszerekkel (faktorelemzés, nem hierarchikus klaszteranalízis) vizsgáljuk, továbbá korrelációelemzéssel kísérletet teszünk a kulturális fejlettség vagy lemaradás és a kistérségek komplex fejlettsége közötti összefüggések számszaki megragadására.

KEYWORDS: culture, cultural traits, cultural economy, factor analysis, cluster analysis, development

ABSTRACT: Assessing the economic role of culture and interpreting it in connection with regional development are becoming increasingly important. Cultural economics as a virtually new branch of economics deals with the possible applications of economic analysis to creative and knowledge-based processes, performing arts, cultural traits, cultural heritage and industries. It is concerned with the economic organisation of the cultural sector, too.

In this study the authors aim to reflect on the assessment and possible means of quantification for the cultural economy of regions. While seeking to gain an insight as to how segments of the cultural economy may be examined using information available in statistical databases both foreign (Eurostat, Eurobarometer, Compendium Information System, Urban Audit) and domestic (Hungarian Central Statistical office), it also provides an empirical analysis of micro-regions in Hungary.

Given that the authors were compelled to restrict the analysis to the segment of cultural traits, attempts were made in investigating the cultural performance of Hungarian microregions using multivariate statistical methods (principal component analysis, non-hierarchical cluster analysis), as well as the numerical correlations between cultural development/distress and the complex development of micro-regions. Through the empirical investigations the authors

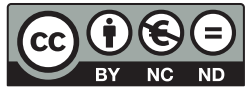


identify and describe the different spatial structures of cultural traits in Hungary with special regard to these cultural sectors: education and amusement (first principal component), participation in cultural forms (second principal component), supply of museums and public institutions (third principal component) and the infrastructure of culture (fourth principal component). After typifying the Hungarian micro-regions by non-hierarchical clustering the authors conclude that more cultural potentials are concentrated in micro-regions where there are large cities or especially attractive medium-sized towns than can be found in other territories. In addition to these findings, significant differences can be observed regarding the micro-regions of West- and South-Transdanubia and the Great Plain.

\section{Bevezetés: a kultúraelemzés néhány regionális vonatkozása}

A hagyományos értelemben vett kultúrafogalom átalakulóban van. A kultúra tradicionális, hosszú múltra visszatekintő humán tartalmának megőrzése mellett felerősödött társadalmi (szociológiai), környezeti (ökológiai) és gazdasági (pénzügyi és menedzsment) vonatkozása, ezért a kultúrafogalom minden elemére és alrendszerére kiterjedő meghatározás napjainkban szinte lehetetlennek tünik. Többnyire konszenzus mutatkozik viszont abban, hogy a kultúrával kapcsolatos viták legújabb hulláma a kilencvenes években és az ezredforduló után jelentkezett (Benko 2002; Nagy, Boros 2010), valamint megállapítható az is, hogy a diskurzusok kereszttüzében kibontakozott irányzatok egyik szegmense a globalizációs trendek és a helyi kultúrák kölcsönhatásaival is mélyrehatóan foglalkozik (Barnes 2003; Tamás 2003). A kultúrával kapcsolatos helyi szempontok előtérbe kerülése jelzi, hogy a regionális tudományban - különösen napjainkban - kiemelt figyelmet kell fordítani a kultúra különböző összetevőinek akkurátus térszerkezeti tanulmányozására, valamint a kultúra sajátos térbeli megnyilvánulásának elemzésére, értékelésére.

Habár a kultúra egyértelmű meghatározása rendkívül bonyolult feladat - e tanulmány keretei között a definíciók ütköztetésére nem is vállalkozhatunk -, mégis hivatkozunk egy igen rokonszenves megközelítésre, amely csaknem teljességében kívánja a fogalom lényegét megragadni. Geertz (1994) szerint a kultúra nem más, mint jelentést hordozó szimbólumok szervezett rendszere, társadalmilag teremtett jelentésstruktúrák összessége, valamint a szimbólumokban megtestesülő jelentések történetileg közvetített mintája. Hozzáteszi azt is, hogy a szimbolikus formák és rendszerek egyrészt örökölhetők, másrészt a társadalom tagjai ezek segítségével kommunikálnak, tanulnak és fejlesztik attitűdjeiket, ezen kívül a szimbólumokhoz való kötődés új fogódzókat kínálhat a helyi közösségek fejlődése esetében. Geertz munkájában kiemeli a kultúra elemzésének fontosságát is, amelyet a „jelentés nyomába szegődő", értelmező tudománynak tart.

A kultúra meghatározásán kívül nagy kihívást jelent a kulturális javak és a kultúra belső tartalmának pontos meghatározása. Daubner és szerzőtársai 
(2000) olvasatában kulturális javak alatt a művészeti tevékenységek eredményeképpen létrejövő, a gazdaság kulturális ágazatába sorolt termékek és szolgáltatások összessége értendő. A kultúra belső tartalmi különbségeire ugyanakkor Huff (2010) mutatott rá széles látókörrel, aki szerint markáns eltérés tapasztalható az egyes népcsoportok értelmezésében, annak ellenére, hogy megmaradt a latin kultúrafogalom (cultura) humán tartalma. A német nyelvterületen a kultúra (Kultur) kifejezés az ember legemberibb sajátosságaira utal, ezzel szemben a francia ajkú országokban a kultúra (culture) antropológiai tartalma jellemzően a magas minőségű kultúrára vonatkozik. Az angol kultúrafogalommal (culture) kapcsolatosan pedig megállapítható, hogy elveszítette eredeti értéktartalmát, viszont megjelent a kultúra mint kulturális örökség (és kulturális világörökség), továbbá a kulturális gazdaság (vagy kultúragazdaság) egyre népszerủbb felfogása.

A kulturális örökségek megjelenésével a turizmus és a településmarketing újabban az egyik legdinamikusabb gazdasági ágazattá vált (Erdősi, Sonkoly 2005), valamint a globális turizmus kiteljesedésével a kulturális turizmus települési szintủ fejlesztése egyre fontosabb feladat lett (Bianchini, Parkinson 1993). Boros és Pál (2010) hangsúlyozzák, hogy a látnivalóvá, élményforrássá váló helyek kiválóan illusztrálják a kultúra áruvá válását, de valójában ennél többről van szó, hiszen a kultúra az értéktermelési folyamat elválaszthatatlan részévé vált. A kilencvenes években megfigyelhető volt, hogy egyre többen - és főleg egyre konkrétabban - kezdtek írni a kultúra szerepéről az innovációban és egyáltalán a gazdasági növekedésben (Tamás 2003). Enyedi (2005) kiemeli, hogy a kultúrára épülő gazdaság a modern ökonómia egyik legjobban erősödő és jellegzetes eleme. A gazdaság kulturális környezete ugyanis elősegíti a dinamikus tudásgazdaság létrehozását, továbbá vonzza az azt működtető, magasan kvalifikált munkaerőt. Ez azt jelenti, hogy a képzett munkaerő a lakóhely kiválasztásakor szem előtt tartja, valamint mérlegeli a magas szintű oktatási, kulturális szolgáltatások meglétét és minőségét (Dziembowska-Kowalska, Funck 1999). A kulturális környezet átalakulása egyszerre változtatja meg a gazdaság tőkevonzó képességét, a munkaerőpiacot, a terület idegenforgalmát, végső soron a gazdaság növekedési ütemét, Chartrand (1990) felfogása szerint a negyedik gazdasági szektort létrehozva. A gazdaság napjainkban egyre érzékenyebben reagál a kultúrára, így a kulturális javakat fogyasztók folyamatosan változó igényeire is. Kong (2000) szerint a kultúrának a város imázsával összefüggo", jelentőségteljes értéke megerősítette az imázstudatosság fontosságát a modern gazdaságban. Nem szabad megfeledkezni arról sem, hogy a kultúra elősegíti a kreatív környezet kibontakozását, a társadalmi-kulturális élet ugyanis a kreativitás fontos forrása lehet. Florida $(2003,2007)$ kreatív osztályokról alkotott koncepciójában kissé más megközelítésben, de lényegében a kulturális gazdaságot érintve arról értekezik, hogy a kulturális környezet és annak vonzereje a városok és térségek fejlődésének egyik meghatározó tényezőjévé vált. 
Ray egyik munkájában - idézik Csatári és szerzőtársai (2007) - már az ún. kultúragazdaságot definiálja, és annak négy lehetséges megjelenési formáját mutatja be:

- adott helyhez, térséghez kötődő kulturális erőforrások közvetlen beépítése valamilyen termékbe vagy szolgáltatásba, tulajdonképpen a térség marketingjébe;

- külső kulturális elemek bevitelével sajátos térségi identitás beépítése a térségen kívülieknek eladandó térségi termékekbe;

- a kultúrahordozó termékek térségen belülieknek való eladása, a helyi piacokat bővítő és egyben a belső térségi identitást tovább erősítő kezdeményezések;

- a helyi kultúra hasznosítása innovatív, domináns fejlesztési gyakorlatoktól különböző helyi fejlesztési utak kidolgozásában.

A kultúra, valamint a környezeti és a gazdasági fenntarthatóság szoros összekapcsolódására Thorsby (2001) hívja fel a figyelmet. Véleménye szerint a fenntartható gazdasági, kulturális és környezeti fejlődésnek olyan szimbiózisban kell léteznie, hogy egyik se okozzon lassulást vagy stagnálást. Olyan folyamatokat szükséges gerjeszteni, amelyek mind az ökoszisztéma, mind a társadalom, mind a gazdaság megújulását támogatják. Thorsby a kulturális politika legfőbb feladataként azonosította a rövid távú vagy ideiglenes megoldások számának csökkentését, a fő kulturális erővonalak feltárását és erősítését, valamint ezzel szemben az úgynevezett káros öngerjesztő folyamatok kiküszöbölését.

A kultúragazdaságot, valamint a kultúra területi megnyilvánulásait és fontosságát tárgyaló művek sorát természetesen még hosszasan lehetne folytatni, általánosságban azonban megállapítható, hogy a kultúraértelmezéssel és -elemzéssel összefüggő megközelítések a témakör gyors fejlődése miatt egyre szerteágazóbbak. A sok-sok megítélés és koncepció ellenére egy jelenség egészen bizonyos, és erre Enyedi (2005) tanulmányában kiválóan rámutatott. A kultúra, valamint a kulturális termékek és szolgáltatások a gazdaság egyik legfontosabb növekvő elemét jelentik, ezért a városi gazdaság részeként vizsgálandók, helyet kell kapniuk a városok gazdaságfejlesztési koncepciójában, de a kultúrafejlesztés hagyományos céljai mellett a versenyképességi, tőkevonzási és profitszerzési célok vonatkozásában is. Egyelőre úgy tünik, hogy a településfejlesztési (ezen belül is inkább a városfejlesztési) gyakorlat preferálja ezt az irányt, és ennek eredményeképp a kultúra Európában, de egyre inkább világszerte is stratégiai fontosságú erőforrássá vált.

Tanulmányunk célja, hogy a kultúraelemzési lehetőségekkel összhangban áttekintő képet adjunk e terület mérési lehetőségeiről és a kulturális gazdaság magyarországi helyzetéről, valamint a kultúra számszakilag is megragadható alrendszereinek területi megoszlásában megfigyelhető különbségekről. Munkánk során arra törekedtünk, hogy hazánk kistérségeinek kulturális potenciálját elemezzük, és összehasonlítást végezzünk a komplex fejlettségi vizsgálatok adta eredményekkel. Vizsgálataink során többváltozós statisztikai módszereket 
(faktorelemzés, nem hierarchikus klaszterelemzés) és korrelációszámítást alkalmaztunk a kulturális fejlettség és lemaradás térszerkezeti megragadására. ${ }^{1} \mathrm{~A}$ tanulmány összegzésében végül megkísérlünk felvetni néhány kritikus, vitaindítónak szánt pontot a témakörrel kapcsolatos hazai összefüggésekről.

\section{Indikátorok a nemzetközi és hazai adatbázisokban és kiadványokban}

Az alábbiakban röviden áttekintünk és értékelünk néhány fontosabb uniós és hazai statisztikai adatbázist, valamint uniós kiadványt a kulturális teljesítmény mérésére szolgáló lehetséges mutatók szempontjából.

Az Eurostat nyilvános adatbázisa elsősorban országos szinten gyüjt és publikál adatokat és statisztikai elemzéseket - a regionális statisztikákban nyilvánosan elérhető adatok száma rendkívül csekély -, ezek is elsősorban a kultúra egy szegmensével, nevezetesen a közművelődéssel kapcsolatosak. A szervezet megítélése szerint a legfontosabb indikátoroknak a kulturális foglalkoztatottság szintje, a kulturális szektor vállalati háttere, a kulturális termékek nemzetközi kereskedelme, a kulturális tevékenység értékelése, a háztartások kulturális kiadásai, valamint a kulturális formákban való részvétel minősül. Az Eurostat legfrissebb elemzéseit 2011 áprilisában foglalta össze Cultural statistics című zsebkönyvében (Eurostat 2011), amely a 2007-ben közzétett első kiadás után immáron a második összefoglaló ebben a témában. A publikációk legfőképpen az európai statisztikai rendszer, az UNESCO statisztikai intézete, valamint az Eurobarometer nyilvános adataira támaszkodnak.

Az unió kulturális helyzetéről az Eurobarometer is összeállított egy kiadványt 2007-ben, European cultural values címmel (Eurobarometer 2007). A publikáció az uniós országokra kiterjedő kérdőíves felmérés eredményeit összesíti, elsősorban azzal foglalkozik, hogy mit jelent a kultúra az európai polgárok számára, valamint összeveti egymással az egyes országok kulturális tevékenységét, a kulturális foglalkoztatottságot és a kultúra különböző formáiban való részvételt. A tanulmány érinti a kulturális javak és értékek áramlásának lehetőségeit, továbbá foglalkozik a kultúrának az európai társadalom jövőjében játszott szerepével.

A Compendium információs rendszere is közöl adatokat és táblázatokat az uniós országok kulturális teljesítményéről, bár nem olyan rendszeresen és részletesen, mint az Eurostat. Az összehasonlító táblázatok jelentős része a nyilvános nemzeti és uniós adatbázisokra támaszkodik, az adatbázis országos, jelentős részben már 2010-re is rendelkezésre álló adatokat tartalmaz. A rendszeren belül négy jellegzetes tématerület különböztethető meg:

- a lakosság kulturális életben való részvétele (mozilátogatások száma, internethasználat aránya, kulturális formákban való részvétel);

- a kulturális termékek és értékek piaca, kereskedelme (kulturális termé- 
kek és szolgáltatások árindexe - CUPIX, ${ }^{2}$ a lakosság rekreációs és kulturális kiadásai, kulturális termékek exportja és importja, filmgyártással kapcsolatos indikátorok);

- a kulturális foglalkoztatottság mutatói (a kulturális szférában dolgozók száma, különös tekintettel a nők arányára);

- a kulturális kiadások mutatói (a kormányzat és az alsóbb közigazgatási szintek kulturális kiadásai, a különböző kulturális szektorok kiadásai).

Az uniós adatszolgáltatás kapcsán végül az EU Regionális Politikai Főigazgatóságával és az Eurostattal szorosan együttműködő Urban Audit adatszolgáltatási rendszeréről szólunk, amelyben a kultúra és rekreáció elnevezés alatt harminc indikátor lelhető fel. Ezek közül közvetlenül tizenhárom tartozik a kultúrához, annak is a közművelődési dimenziójához (pl.: könyvtár-, múzeum-, mozi- és színházlátogatások, foglalkoztatottak száma a kultúra és a szórakoztatás területén). A közművelődést mérő mutatószámok a 258 legjelentősebb európai városra (köztük tíz magyar városra) érhetők el. A legfrissebb adatok a 2004-es évből származnak.

Hazánkban a Központi Statisztikai Hivatal (KSH) gyüjt és tesz közzé olyan adatokat, amelyek a kistérségek és települések kulturális teljesítményének, ezen belül a kulturális gazdaság közművelődési dimenziójának jobb leírására szolgálnak. A KSH területi adatbázisa nagyságrendileg harminc mutatót tartalmaz, az indikátorok rendszere nagyrészt megegyezik az Eurostat-adatbázis logikájával. Az adatszolgáltatás nagy előnye, hogy a mutatók települési és kistérségi szinten is rendelkezésre állnak. Általánosságban viszont megállapítható, hogy az a kutató, aki a kulturális gazdaság statisztikai szempontú vizsgálatára vállalkozik, számos problémával szembesül a nyilvános adatok korlátozott elérhetősége miatt. A KSH-ban elérhető adatállomány legalább két hátrányára szükséges felhívni a figyelmet (amelyek egyébként általában az uniós anyagokra és adatbázisokra is igazak):

- Az egyik hátrány, hogy a nyilvános adatok köre ugyan 2006/2007 után jelentősen bővült, de a mutatók a teljes kulturális gazdaság megragadására nem alkalmasak. A közművelődést számszerüsítő indikátorok rendelkezésre állnak, de ezek csupán egy szegmensét képezik a kulturális gazdaság teljes rendszerének. Ez alapján a mutatók a kistérségek vagy települések fejlettségének, fejletlenségének egyértelmű megítélésére nem feltétlenül alkalmasak.

- A másik hátrány abból fakad, hogy a mutatószámok rendszere nem konzisztens a különböző években, a mutatók egymással nem összehasonlíthatók. Az 1990-es években, de még az ezredforduló után is jóval kevesebb, valamint más mutató látott napvilágot, mint az elmúlt pár évben. Egyrészt új mutatók keletkeztek, másrészt néhány régebben használt indikátor megszűnt. Ebből az következik, hogy nem létezik olyan „kontrollév”, amelyhez viszonyítva ki lehetne mutatni, hogy a hazai területi szinteken milyen változások zajlottak le a kulturális adottsá- 
gok, értékek tekintetében, valamint azt sem lehet megállapítani, hogy melyek voltak azok a kistérségek vagy települések, amelyek kulturális helyzetüket tekintve javítottak vagy rontottak pozícióikon.

\section{A hazai kistérségek közmüvelődésének jellemzői: a faktorelemzés eredményei}

Az előző részben megállapítottuk, hogy a kulturális gazdaság összességében nem mérhetö, de annak egyes elemei igen, hiszen az elemzések a közművelödést ${ }^{3}$ leíró szegmensre elvégezhetők. A mutatórendszer hiányosságai miatt - a fentiekben leírtak alapján - idősoros vizsgálatra sem vállalkozhatunk, elemzésünkhöz a 2010-es évet választottuk ki, amelyből kellő számú friss mutató áll rendelkezésre.

Ha átfogó képet szeretnénk kapni a magyarországi kistérségek kulturális helyzetéről, akkor egy olyan vizsgálatra van szükségünk, amely több lokális adottságot és determinánst hordoz magában. Ez azt jelenti, hogy olyan mutatószámrendszert kell kidolgozni, amely legalább tartalmazza:

- a kulturális gazdasággal összefüggésbe hozható tárgyi és intézményi hátteret, valamint annak felszereltségét (pl. közintézmények, müemlékek, múzeumok, könyvtárak, számítógépek száma, internethez való hozzáférés);

- a közművelődési formákban való részvétel alternatíváit és konkrét alakulását (pl. mozi- és könyvtárlátogatás, kulturális rendezvényeken, müvelődési formákban és alkotó-művészi közösségekben való részvétel);

- a kulturális gazdaság oktatással összefüggő tényezőit (pl. felsőoktatásban oktatók és dolgozók száma);

- végül tartalmaznia kell a kulturális-művelődési tevékenység és foglalkoztatottság lenyomatait (a művészeti, oktatási, szabadidős tevékenységek vagy tudományos nemzetgazdasági ágazatban működő regisztrált vállalkozások száma, aránya).

Az elemzésünk alapjául az Országos Területfejlesztési és Területrendezési Információs Rendszer (TeIR) adatbázisából származó KSH-adatok szolgálnak. Ugyan területi egységnek a hazai kistérségeket választottuk, de a leíró statisztika alapján Budapest extrém értékeket képviselt, így kizártuk a további vizsgálatokból és 173 kistérséget vettünk figyelembe a többváltozós elemzésben. Az induló kistérségi adatbázis több mint harminc változót tartalmazott, amelyen - a későbbi klaszterelemzés miatt - adatredukciót végeztünk.

A rendelkezésre álló adatok alkalmasságát a faktorelemzés több módszerével vizsgáltuk, amely megerősítette, hogy a bevont változók megfelelőek a faktoranalízisre. A faktorrotációs módszer segítségével eredeti változóinkat négy látens dimenzióba tudtuk sűríteni, összesen huszonhat olyan mutatóval dol- 
1. táblázat: A főkomponenselemzés összetevői Indicators of the principal component analysis

\begin{tabular}{|c|c|c|}
\hline & Fókomponensek és változók & Súly \\
\hline \multicolumn{3}{|c|}{ 1. Kulturális szektor, oktatás és szórakozás fókomponense } \\
\hline 1. & 1000 vállalkozásra jutó regisztrált vállalkozások száma a szakmai, tudományos, & \\
\hline & műszaki tevékenység nemzetgazdasági ágban & 0,876 \\
\hline 2. & 1000 lakosra jutó mozilátogatások száma & 0,796 \\
\hline 3. & $\begin{array}{l}1000 \text { lakosra jutó felsőoktatási intézményekben dolgozók száma (képzés helye } \\
\text { szerint) }\end{array}$ & 0,774 \\
\hline 4. & $\begin{array}{l}1000 \text { vállalkozásra jutó regisztrált vállalkozások száma a művészet, szórakoztatás, } \\
\text { szabadidő nemzetgazdasági ágban }\end{array}$ & 0,772 \\
\hline 5. & 1000 lakosra jutó mozielőadások száma & 0,772 \\
\hline 6. & 1000 lakosra jutó felsőoktatásban részt vevő hallgatók száma (képzés helye szerint) & 0,765 \\
\hline 7. & $\begin{array}{l}1000 \text { vállalkozásra jutó regisztrált vállalkozások száma az oktatási nemzetgazdasági } \\
\text { ágban }\end{array}$ & 0,758 \\
\hline 8. & 1000 lakosra jutó internet-előfizetések száma & 0,707 \\
\hline 9. & 1000 lakosra jutó kábeltelevízió-előfizetők száma & 0,702 \\
\hline 10. & 10000 lakosra jutó szabadalmi bejelentések száma & 0,550 \\
\hline
\end{tabular}

2. Közmüvelödési formákban való részvétel fökomponense

1. 1000 lakosra jutó alkotó-művészi közösségek száma $\quad 0,831$

2. 1000 lakosra jutó alkotó-művészi közösségek tagjainak száma $\quad 0,803$

3. 1000 lakosra jutó rendszeres művelődési foglalkozások száma 0,767

4. 1000 lakosra jutó kulturális rendezvények száma $\quad 0,732$

5. 1000 lakosra jutó rendszeres művelődési formákban részt vevők száma $\quad 0,608$

6. 1000 lakosra jutó kulturális rendezvényeken részt vevők száma $\quad 0,594$

3. Múzeumok és közintézmények ellátottsága fókomponens

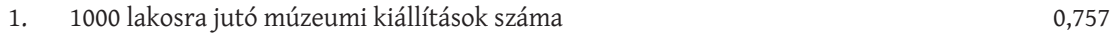

2. 1000 lakosra jutó muzeális intézmények száma $\quad 0,746$

3. 1000 lakosra jutó műemlékek és műemléki jelentőségủ területek száma $\quad 0,683$

4. 1000 lakosra jutó múzeumi látogatók száma $\quad 0,646$

5. 1000 lakosra jutó könyvtárral ellátott közintézmények száma $\quad 0,628$

6. 1000 lakosra jutó számítógéppel ellátott közintézmények száma $\quad 0,460$

4. Kulturális háttér-infrastruktúra fókomponense

$\begin{array}{ll}\text { 1. } \quad 1000 \text { lakosra jutó személyi számítógépek száma } & 0,885\end{array}$

2. 1000 lakosra jutó internetfelhasználók száma $\quad 0,843$

3. 1000 lakosra jutó nyilvános könyvtárak száma $\quad 0,663$

4. 1000 lakosra jutó közművelődési intézmények száma $\quad 0,540$

Megjegyzés: Az egyes rotált faktorok tartalmával, 1,0 sajátérték-szint mellett, Varimax-rotációval és Kaiser-kritériummal. Faktorsúlyhatár: 0,450. KMO-kritérium: 0,757. Barlett-teszt: $\chi^{2}=3880,216$; df=325; p=0,00. MSA-értékek: 0,520 és 0,916 között. Magyarázott varianciahányad: 62,209\%.

Forrás: saját szerkesztés. 
gozhattunk tovább, amelyek domináns szerepet játszanak a kistérségek közmüvelődési teljesítményének megítélésében (1. táblázat).

A kulturális szektor, oktatás és szórakozás fókomponense - tíz mutatóval - összefoglalja a kulturális gazdasággal összefüggésbe hozható nemzetgazdasági ágazatok regisztrált vállalkozásainak, továbbá a felsőoktatásban tanulók és dolgozók számát és a lakosság szabadidő-eltöltésével (internethasználat, kábeltelevízió-előfizetés, moziba járás) kapcsolatos mutatószámait. A faktor összetevői rávilágítanak arra, hogy azokban a kistérségekben, ahol a kulturális ágazatokban müködő vállalkozások nagy számban vannak jelen, ott kedvezőbbek a felsőoktatás feltételei, tehát a két jelenség nagyobb valószínűséggel fordul elő együttesen. Az első főkomponenshez tartozó faktorpontértékek alapján megállapítható, hogy a legelőkelőbb pontértékekkel azok a kistérségek rendelkeznek, ahol nagy- vagy jelentősebb középváros - ritkább esetben kisváros - található. Ez a jelenség nem meglepő, hiszen alapvetően e kistérségekben találhatók a felsőfokú oktatási intézmények. A megyeszékhelyekkel rendelkező kistérségeken kívül néhány főváros környéki és észak-dunántúli kistérség minősül e téren nagyobb számban megfelelőnek. Ezzel szemben határozottabb lemaradást tudhat magáénak Bács-Kiskun, illetve SzabolcsSzatmár-Bereg megye több kistérsége, valamint több határ menti területegység (elsősorban az ország déli területein) (1/a. ábra).

A közművelődési formákban való részvétel főkomponense összesen hat indikátort foglal magában. Ez a dimenzió a kulturális rendezvényeken való részvételt, az alkotó-művészi közösségek és a rendszeres művelődési foglalkozások

1. ábra: A hazai kistérségek faktorpontértékei az egyes faktorokban Factor scores of Hungarian micro-regions
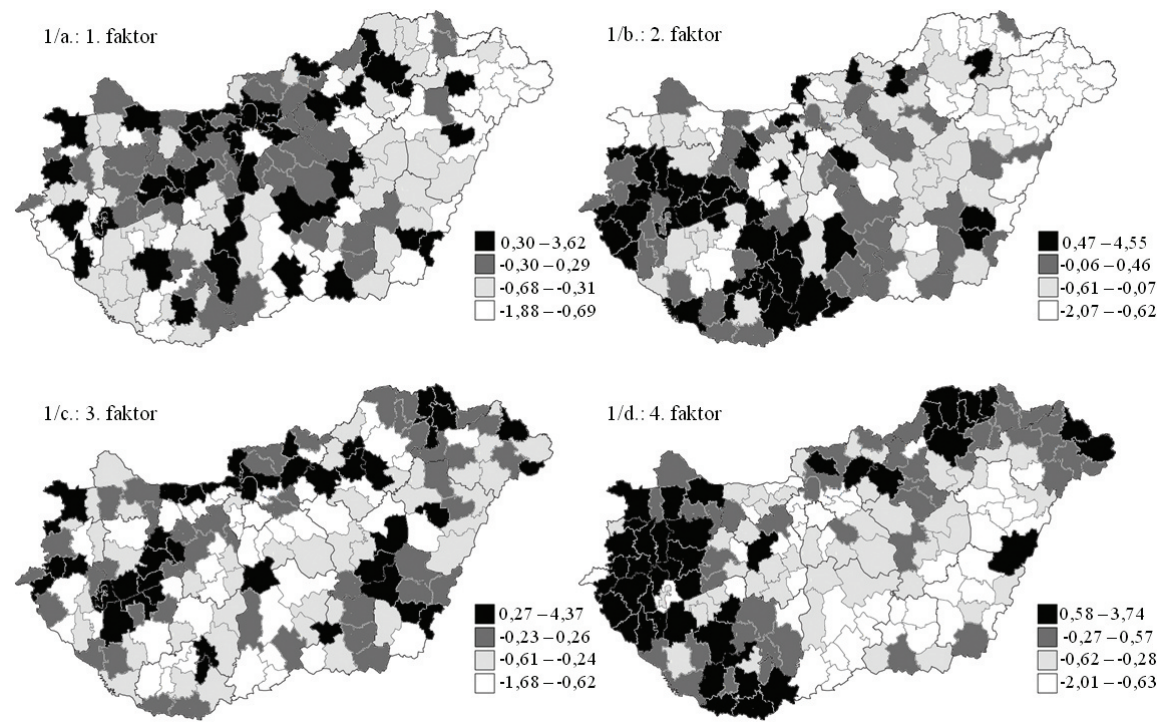

Forrás: saját szerkesztés. 
jellemzőit tartalmazza. A súlyok alapján megállapítható, hogy az alkotó-művészi közösségekről számot adó mutatók konstrukciós ereje a legjelentősebb. E dimenzió már bonyolultabb térszerkezeti összefüggésekről árulkodik, nevezetesen a közművelődési formákban való részvétel a nagyobb városokkal nem rendelkező kistérségekben nagyobb, tehát a jelenség inkább rurális, mint urbánus. A dunántúli megyék közül Baranya, Tolna, Vas, Veszprém és Zala megye, ezen kívül pedig Bács-Kiskun megye egyes kistérségei rendelkeznek a legelőkelőbb pontszámokkal, míg hazánk északkeleti részén e dimenzió tekintetében is markánsabb a lemaradás ( $1 / b$. ábra).

A faktorelemzés eredményeképpen létrejött harmadik dimenzió - a múzeumok és közintézmények ellátottsága főkomponens - mutatói már nem a kulturális programokra és rendezvényekre vonatkoznak, hanem a kultúra intézményeire utalnak. Érdekesség, hogy a második és harmadik főkomponens összetevői nem kapcsolódnak össze, így nem mondhatjuk azt, hogy a közművelődési formákban való részvétel, valamint a közintézmények ellátottsága között szoros összefonódás van. E főkomponens térszerkezetéről megállapítható, hogy a legkiválóbb pontértékkel rendelkező kistérségek a Balaton körül (elsősorban Veszprém megye déli részén), a Komárom-Eger-vonalon, néhány északkeletmagyarországi kistérségben és Békés megyében találhatók, de nem alkotnak markánsan egybefüggő területet. A lemaradó kistérségekkel kapcsolatosan is hasonlóak mondhatók el: ugyan a fővárostól közvetlenül délre elterülő területi egységek átlag alatti pontértékekkel rendelkeznek, de ilyen jellegü területek az ország szinte minden szegletében megtalálhatók (1/c. ábra).

Végül a háttér-infrastruktúra főkomponense közvetlenül négy változót sürít össze, amelyek elsősorban a kultúra anyagi hordozóira, közvetítő eszközeire (személyi számítógép, internet, könyvek, intézmények) utalnak. A nagyobb területegységek szerint legjobban körülhatárolható, egyben jól differenciálható térszerkezetet tulajdonképpen ez a dimenzió rajzolja ki, ugyanis a Dunántúl szinte teljes nyugati része - néhány dél-dunántúli és észak-magyarországi kistérséggel kiegészülve -, valamint a Budapest környéki és az alföldi megyék erőteljes kontrasztot mutatnak. E vonatkozásban tehát megfigyelhető egy nyugat-keleti lejtő (1/d. ábra).

\section{A hazai kistérségek csoportosítási lehetőségei}

A hazai kistérségeket a keletkezett négy főkomponens alapján vizsgáljuk a továbbiakban, úgy, hogy a faktoranalízis során képzett sűrített mutatók segítségével nem hierarchikus módszerrel, ún. K-közép klaszterelemezéssel osztályozzuk a magyarországi kistérségeket. Célunk az, hogy a kistérségeket még szemléletesebben el tudjuk különíteni a közművelődés szempontjából. Több lehetséges klaszterszám értékelése után úgy döntöttünk, hogy öt részre bontjuk a kistér- 
ségek halmazát (2. ábra). Ezen kívül figyelmet fordítottunk arra is, hogy azonosítsuk az egyes csoportok legfőbb tulajdonságát, a klaszterközéppontokat (2. táblázat).

A klaszterközéppontok összevetése nyomán a magyarországi kistérségek öt típusát különítettük el:

- 1. klaszter: Jelentős kulturális kapacitással rendelkezö központok. Elsősorban megyei jogú városokkal rendelkező kistérségek (az Érdi, Hódmezővásárhelyi, Nagykanizsai, Szekszárdi és Zalaegerszegi kistérségeket kivéve), valamint

2. ábra: A kistérségek tipizálása a K-közép módszer alapján Classifying the micro-regions based on the K-means clustering method

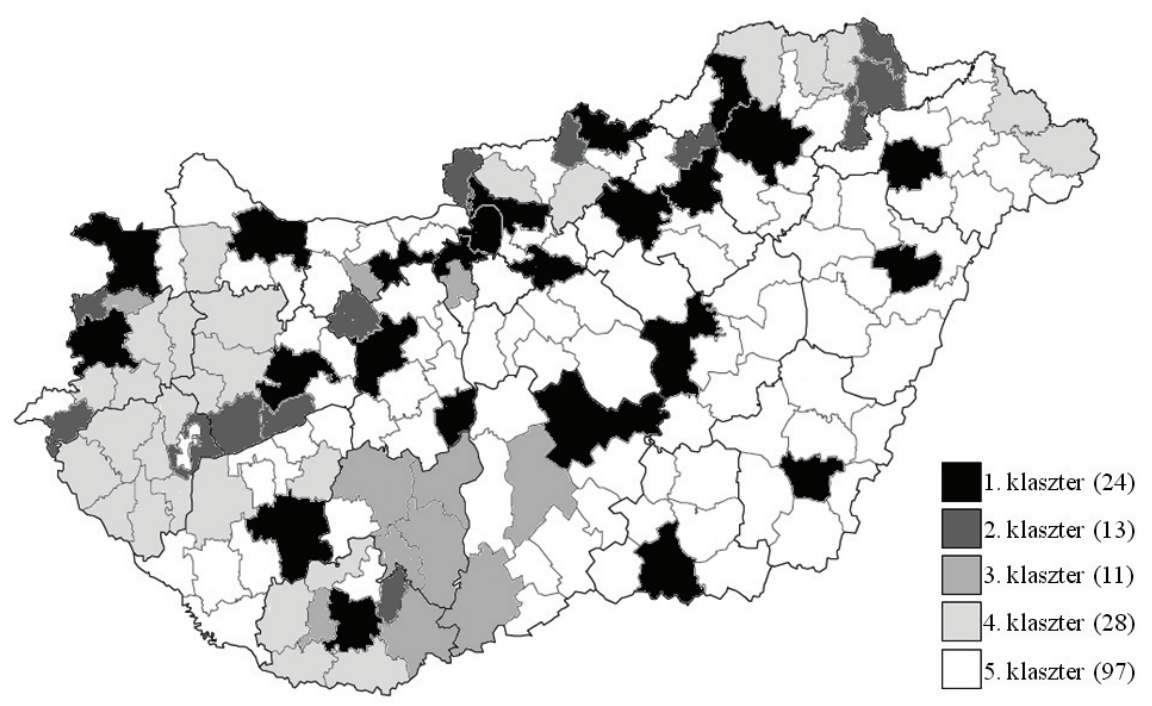

Forrás: saját szerkesztés.

2. táblázat: A nem hierarchikus klaszterelemzés csoportjainak középpontjai Final cluster centers of the non-hierarchical cluster analysis

\begin{tabular}{|c|c|c|c|c|c|c|c|c|c|}
\hline \multirow{3}{*}{$\begin{array}{l}\text { Klaszterek } \\
1\end{array}$} & \multirow{3}{*}{$\begin{array}{l}N \\
24\end{array}$} & \multicolumn{8}{|c|}{ Klaszterközéppontok } \\
\hline & & \multicolumn{2}{|c|}{ 1. fókomponens } & \multicolumn{2}{|c|}{ 2. fökomponens } & \multicolumn{2}{|c|}{ 3. fókomponens } & \multicolumn{2}{|c|}{ 4. fókomponens } \\
\hline & & 2,01 & magas & $-0,31$ & közepes & 0,04 & közepes & 0,26 & magas \\
\hline 2 & 13 & $-0,31$ & közepes & 0,72 & magas & 2,69 & magas & $-0,04$ & közepes \\
\hline 3 & 11 & 0,03 & közepes & 2,17 & magas & $-0,69$ & alacsony & $-0,33$ & közepes \\
\hline 4 & 28 & $-0,46$ & közepes & 0,07 & közepes & $-0,17$ & közepes & 1,51 & magas \\
\hline 5 & 97 & $-0,33$ & közepes & $-0,29$ & közepes & $-0,24$ & közepes & $-0,46$ & közepes \\
\hline Összesen & 173 & & & & & & & & \\
\hline
\end{tabular}

Megjegyzés: A három kimenetelű (magas, közepes, alacsony) osztályozásnál a harmadolópontokból $(33,3 \%, 66,7 \%)$ indultunk ki. N=kistérségek száma.

Forrás: saját szerkesztés. 
néhány egyéb, jelentősebb középvárossal (Gödöllő, Gyöngyös, Vác) rendelkező kistérség sorolható e csoportba, amelyek legfőbb jellemzője a kiugró kulturális ágazatok, oktatás, szórakozási lehetőségek, valamint a magas színvonalú kulturális (háttér)infrastruktúra jelenléte.

- 2. klaszter: Potenciális kulturális térség, jelentős alkotói-müvészi, illetve kiemelkedő múzeumi, müemléki kapacitással. A csoport azokat a térségeket tartalmazza, amelyek az alkotó-művészi közösségek és a kulturális rendezvények tekintetében átlag feletti potenciállal, a közművelődési intézmények ellátottságát illetően pedig kiváló adottságokkal rendelkeznek. Elhelyezkedésük országos viszonylatban rendkívül elaprózott, a térségek a Dunántúl legnyugatibb részén éppúgy megtalálhatók, mint Észak-Magyarországon.

- 3. klaszter: Potenciális kulturális térség, kiemelkedő alkotói-müvészi kapacitással. A klaszter azokat a kistérségeket tömöríti, amelyek a közművelődési formákban való részvételt leszámítva átlagos vagy átlag alatti teljesítménnyel bírnak. E csoport kistérségeinek jelentős része a Dél-Dunántúlon - elsősorban Tolna megyében - összpontosul.

- 4. klaszter: Átlagos (mérsékelt) kulturális kapacitással rendelkező térségek. Olyan térségek sorolhatók ide, amelyek a kulturális infrastruktúra terén ugyan kiemelkednek, de ezt az adottságukat csupán átlagos mértékben tudják kamatoztatni a közmüvelődés puha dimenzióit tekintve. A csoport magját leginkább Vas, Veszprém és Zala megye kistérségei adják, de tagjai elszórtan Baranyában, Borsodban, Nógrádban és SzabolcsSzatmár-Bereg megyében is megtalálhatók.

- 5. klaszter: Fejlődő vagy kultúrahiányos térségek. Az ötödik csoport nagy számú kistérséget tömörít, amelyek mindegyik dimenziót tekintve elmaradnak a többi csoport tagjaitól. A természetföldrajzi értelemben vett Alföld területén (a Mezőföldet is ideértve) található kistérségek nagy súlyt képviselnek e klaszterben (a jelentősebb városokkal rendelkező térségeket leszámítva), de Belső- és Külső-Somogy, valamint az északi határ mentén elterülő területi egységek egy része is ide tartozik.

\section{A kistérségek közmüvelődési teljesítménye és fejlettsége közötti kapcsolat}

Kutatásunk során végül arra a kérdésre kerestük a választ, hogy a klaszteranalízis eredményeként kirajzolódó csoportok hogyan követik a magyar kistérségek komplex - vagyis gazdasági, infrastrukturális, társadalmi, szociális és foglalkoztatási jellemzőit együttesen visszatükröző - fejlettségét, amelyhez a KSH Tájékoztató a kiemelten támogatott kistérségekról címü kiadványa szolgált bővebb felvilágosítással (3. ábra) (KSH 2008). 


\section{3. ábra: A kistérségek komplex fejlettsége} Development of micro-regions

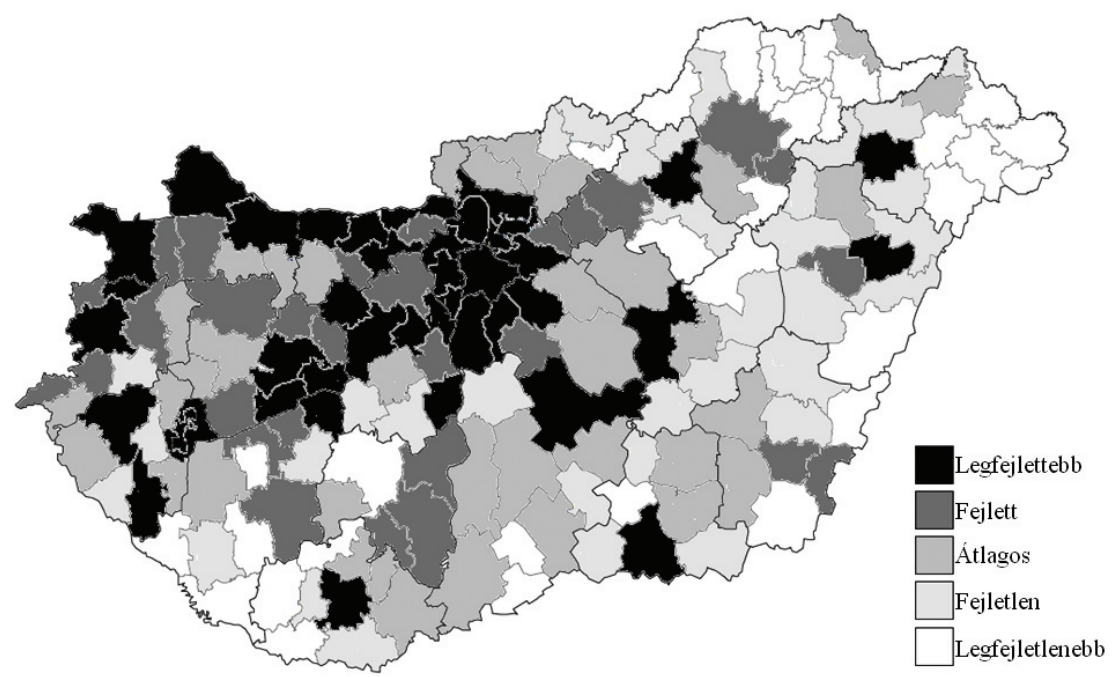

Forrás: KSH 2008.

A kistérségek közművelődési teljesítménye és komplex fejlettsége közötti összefüggést korrelációszámítással vizsgáltuk, külön elemezve a négy főkomponens faktorpontértékeit, valamint a komplex fejlettségi vizsgálat adta pontszámokat:

- Az első főkomponens esetében a korrelációs érték 0,655 ( $\mathrm{p}=0,00)$, így a kulturális ágazatok, felsőoktatás és szórakozás, valamint a kistérségek fejlettsége között közepesen erős összefüggés van.

- A második fókomponens vizsgálata során a korrelációs érték 0,278 $(p=0,00)$, amely a közművelődési formákban való részvétel és a kistérségek fejlettsége között közepesnél gyengébb kapcsolatot fejez ki.

- A harmadik és negyedik fókomponens esetében gyenge összefüggés azonosítható, tehát a múzeumok és közintézmények ellátottsága, valamint a közintézmények háttér-infrastruktúrája és a kistérségek fejlettsége között nincsen egyértelmű kapcsolat.

A kistérségek kulturális-közművelődési adottságai és a komplex fejlettség közötti kapcsolatokat térképen is ábrázoltuk (4. ábra). A kutatás során akkor minősült egy kistérség a legfejlettebbnek, ha a komplex fejlettség szempontjából a legfejlettebb kategóriába tartozott és az általunk futtatott K-közép módszer eredményei alapján is az első klaszterbe sorolható. A fejlett kistérségek csoportjába azok a kistérségek kerültek, amelyek a komplex fejlettség tekintetében legalább fejlett teljesítménnyel rendelkeznek és ezzel párhuzamosan vagy jelentős kulturális kapacitással rendelkeznek, vagy potenciális kulturális kistérségek. A fejletlen kategóriába tartozó kistérségeket több rendezőelv mentén jelöljük ki: 
- vagy legfeljebb átlagos teljesítményűek a komplex vizsgálat alapján és mérsékelt, vagy fejlődő/kultúrahiányos térségeknek minősülnek;

- vagy fejlett kistérségek a komplex vizsgálat alapján, de egyértelműen a kultúrahiányos területekhez sorolhatók.

Az ötödik, vagyis a legfejletlenebb kategóriában azok a kistérségek foglalnak helyet, amelyekben a fejletlenség mérsékelt kulturális kapacitással párosul vagy ennél rosszabb a helyzet valamelyik - esetleg mindkét - dimenzióban. Minden más kistérséget az átlagos kategóriába soroltunk.

Az összetett vizsgálat eredményeként tizenhét olyan kistérségről számolhatunk be, amely a komplex fejlettség tekintetében az élmezőnyhöz tartozik, ezzel párhuzamosan jelentős kulturális kapacitással is bír (Debreceni, Dunaújvárosi, Egri, Gödöllői, Győri, Kaposvári, Kecskeméti, Nyíregyházai, Sopron-Fertődi, Szegedi, Székesfehérvári, Szentendrei, Szolnoki, Szombathelyi, Tatabányai, Váci, Veszprémi kistérség). Tizenegy olyan térség van, amely szorosan követi az első csoportot (Balatonfüredi, Békéscsabai, Budaörsi, Csepregi, Gyöngyösi, Keszthelyi, Kőszegi, Miskolci, Pécsi, Tapolcai, Zirci kistérség), többségük az élmezőnyhöz tartozó kistérségekkel határos, de legalábbis földrajzi szempontból azok közelében van. A kistérségek legnagyobb számban azonban a fejletlen (51), illetve a legfejletlenebb (53) csoportba tömörülnek, jelezve, hogy a társadalmi-gazdasági lemaradás és a közművelődés kemény és puha tényezőinek hiánya szorosan összefügg egymással. A legfejletlenebb területek ezen összevont dimenzióban mindenekelőtt a Tisza vonalától keletre összpontosulnak, de Külső-Somogy és Borsod kistérségei is magukon viselik a gyengébb társadalmi, gazdasági és kulturális jegyeket.

4. ábra: A közművelődési jellemzők és a komplex fejlettség együttes tipizálása Combined classification of cultural traits and complex development

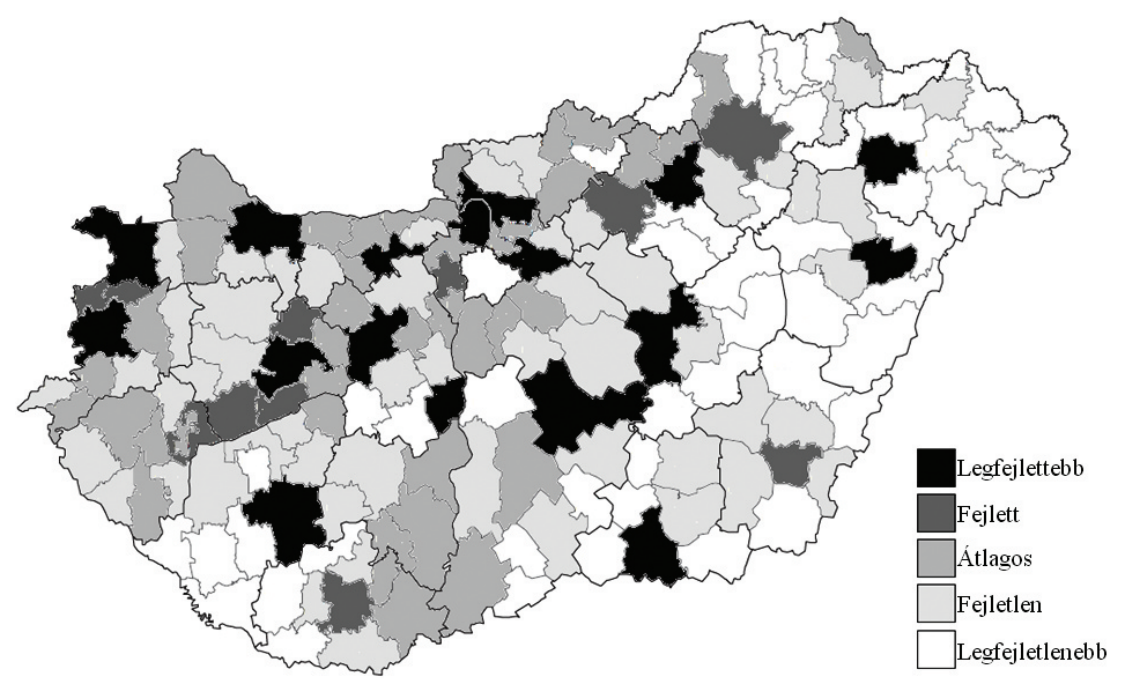

Forrás: saját szerkesztés. 


\section{Összegzés}

Az emberek univerzális igénye, hogy „értelmes”, jelentéssel bíró, kulturált világban éljenek; még akkor is, ha a globális kultúra nem ritkán leegyszerüsített, könnyen feldolgozható üzenetei több helyütt érezhetően felváltják a közművelődés nyújtotta valódi értékvilágot. Nyilvánvalóan egyre gyakrabban fel kell tennünk azt a kérdést, hogy értelmezhető-e eredeti tartalmában a közművelödés szó, és hogy amit a statisztika ma mér - vagyis amit tanulmányunkban elemezhettünk -, az valójában milyen mértékben a köz művelődése.

Dolgozatunk karakterét három szempont alakította, egyben sommázza. Egyrészt a kultúrafogalom belső tartalmi átalakulásának jellemzőit és a kultúraelemzés alternatíváit kerestük, amellyel kapcsolatban arra a következtetésre jutottunk, hogy a geertzi értelemben vett kultúrafelfogás és értékkeresés megvalósíthatatlan a mélységi, sokváltozós empirikus elemzés nélkül. Másodsorban elvégeztünk egy statisztikailag jól megfogható, de nem teljes körü elemzést, amely görbe tükröt tart elénk azon visszás helyzetről, miszerint ha ma valamely alsóbb területi szinten szeretnénk elemezni a kulturális környezetet és gazdaságot, akkor csak szük statisztikai mezsgyén és adatsorokkal dolgozhatunk. A statisztikai adatok köre messze nem fedi le a kultúrafogalom valódi tartalmát. Tanulmányunk második pontjában említést tettünk olyan indikátorokról, amelyek bevonása feltétlenül kívánatos lenne a kulturális gazdaság komplexebb megragadásához. Végül nyilvánvaló számunkra, hogy az elemzésből ezek után nem vonhatunk le messzemenő következtetést. Ez az adatgyüjtés ugyanis a statisztikai felvételek korlátozottságából és gyakori inkonzisztenciájából fakadóan nem vethető össze egy olyan kultúrakutatással, amelyben kvantitatív és kvalitatív eszközökkel nyert információk állnak rendelkezésre.

Jelen vizsgálat viszont megfelelő alapot adhat a kulturális gazdasággal kapcsolatos elemzések folytatásához. ${ }^{4}$ Az elemzés egyértelműen rávilágított arra, hogy számos kistérség nem rendelkezik olyan feltételekkel, amelyben a gazdaság fejlődéséhez is megfelelő kulturális miliő kialakulna. A vizsgálat segítségével jól láthatóvá váltak a meghatározóbb közép- vagy felső szintű centrumok, valamint a lemaradó vidéki terek közötti különbségek. A klaszterelemzéssel beláttuk, hogy a magyar kistérségek több mint fele minden vizsgált dimenzió szempontjából átlagos vagy kedvezőtlenebb paraméterekkel rendelkezik, további közel húsz százaléka pedig a lecsúszás ellen küzd. Az eredményeket a közmüvelődés és a társadalmi-gazdasági fejlettség együttes vizsgálata is megerősítette. A korrelációelemzés eredményei rávilágítottak arra, hogy a közművelődés területén csak a jelentősebb városokat tartalmazó kistérségek esetében lehet a kultúra gazdaságfejlesztési forrás. A közművelödési formákban való részvétel azonban érdekes módon a rurális terekhez kapcsolódik, igaz, e dimenzió tekintetében is igen éles a kontraszt, elsősorban nyugat-keleti viszonylatban.

Természetesen a kulturális javak fogyasztásával kapcsolatos igény minden, ember által lakott térben felmerül - függetlenül a térség urbánus vagy rurális 
jellegétől -, de a kultúra iránti szükségletek kielégítése továbbra is a jelentősebb (nagy- és közép-) városokhoz kötődik. Ezzel összefüggésben igen lényeges kérdésként merül fel, hogy miként terjeszthető ki a városok által generált magas minőségű kultúra a vidéki területekre a megfelelőbb „kulturális nivellálódás" céljából. Jelenleg úgy tűnik, hogy Magyarországon a kultúra és a területi fejlődés közötti összefüggés felismerése, valamint ennek a helyi/regionális politikába való beépítése kevésbé jellemző. Egy megfelelőbb, a kulturális szegmenst is nagyobb súllyal figyelembe vevő szakpolitika viszont feltétlenül hozzájárulhat a kultúra háttérfeltételeinek, infrastruktúrájának és a kulturális gazdaság egyensúlyának megtartásához, felerősítheti az új, magasabb minőségü formák megjelenését és elterjedését. Ehhez természetesen arra is szükség van, hogy a politikai döntések mentén létrejövő fejlesztések a helyi társadalom valódi igényeit és fejlődését szolgálják, és ne pusztán gazdasági szempontok érvényesüljenek a döntéshozatal során. E problémakör további tanulmányozása feltétlenül szükséges volna.

A jelenlegi kutatás jövőbeni irányaival kapcsolatosan megállapítható, hogy a kulturális teljesítményt nem csupán hazai, hanem nemzetközi, de legalább határon átnyúló viszonylatban is érdemes lenne vizsgálni és értékelni. Ezen kívül a telephelyválasztás vagy a vállalati sikeresség vizsgálatakor a gazdasági és társadalmi változók alakulása mellett a kultúra fundamentális tényezőit is célszerű lenne számításba venni a jövőben, a jól körülhatárolható kulturális vonások ugyanis megfelelő alapot szolgáltathatnak a területi versenyképesség még szélesebb értelmezéséhez.

\section{Jegyzetek}

1. Elemzéseinkhez az SPSS 20.0 verzióját használtuk.

2. A CUPIX (Cultural Price Index on Goods and Services), vagyis a kulturális termékek és szolgáltatások árindexe válogatott termékek és szolgáltatások vásárlóerő-paritásos adataiból tevődik össze. A CUPIX-mutató két dimenziót tartalmaz. Az egyik a kulturális iparágak fogyasztói árai (CICP), amely a leginkább keresett elektronikus adathordozók és „bestseller” könyvek, valamint a legújabb filmipari termékek árainak egyszerü számtani átlagán alapul. A másik dimenzió a közösségi művészeti szolgáltatások indexe (PASP), amelyet a múzeumi jegyárak, az operaelőadások jegyárainak, valamint a zeneiskolákban tartott órák árának egyszerü számtani átlagaként határoznak meg.

3. A közművelődés e dolgozat keretein belül a kulturális szféra egyik ágazatára utal, amely kifejezi a lakosság tanulási, alkotói és művelődési célzatú tevékenységét, felöleli a lakosság kultúrahasználatát, és hozzájárul a humán erőforrás fejlődéséhez, valamint az életminőség javításához.

4. Ennek módszertanát a jövőben a Szegedi Tudományegyetem és a Miskolci Egyetem kutatóival közösen kívánjuk kialakítani, és annak helyességét három, eltérő adottságokkal rendelkező hazai kistérség feldolgozásával bizonyítani. 


\section{Irodalom}

Barnes, T. (2003): The culture of the economy. Introduction. In: Anderson, K., Domosh, M., Thrift, N., Pile, S. (eds.): Handbook of cultural geography. SAGE, London, 89-97.

Benko, G. (2002): Regionális tudomány. Dialóg Campus Kiadó, Budapest, Pécs

Bianchini, F., Parkinson, M. (eds.) (1993): Cultural policy and urban regeneration: the West European experience. Manchester University Press, Manchester

Boros L., Pál V. (2010): A kulturális gazdaság globalizálódásának néhány földrajzi aspektusa. In: Mészáros R., Boros L., Nagy E., Nagy G., Pál V. (szerk.): A globális gazdaság földrajzi dimenziói. Akadémiai Kiadó, Budapest, 249-277.

Chartrand, H. H. (1990): The hard facts: perspectives of cultural economics. Transactions of the Royal Society of Canada 1989. 4. University of Toronto Press

Csatári B., G. Fekete É., Farkas J., Osgyáni G., Baksa S. (2007): A környezet és a kultúra szerepe a vidéki változásokban. In: Banczerowski J., Koncz I., Baranyainé Szabó P., Szentpéteri J., Koncz I., Szemenyei I. (szerk.): Stratégiai kutatások 2006-2007. Kutatási jelentések. MTA-MEH, Budapest, 303-327.

Daubner K., Horváth S., Petró K. (szerk.) (2000): Kultúra-gazdaságtani tanulmányok. Aula Kiadó, Budapest

Dziembowska-Kowalska, J., Funck, R. H. (1999): Cultural activities: source of competitiveness and prosperity in urban regions. Urban Studies, 8., 1381-1398.

Eurobarometer (2007): European cultural values. Special Eurobarometer, 278. European Commission, Brussels

Enyedi Gy. (2005): A városok kulturális gazdasága. In: Enyedi Gy., Keresztély K. (szerk.): A magyar városok kulturális gazdasága. MTA TKK, Budapest, 13-27.

Erdősi P., Sonkoly G. (2005): A kultúra melankóliája. A kulturális örökség fogalmának megjelenése. Világosság, 6., 73-90.

Eurostat (2011): Cultural statistics. Publication Office of the European Union, Luxembourg

Florida, R. (2003): The rise of the creative class. Basic Books, New York

Florida, R. (2007): The flight of the creative class: the new global competition for talent. Basic Books, New York

Geertz C. (1994): Az értelmezés hatalma. Századvég Kiadó, Budapest

Huff, E. B. (2010): A kulturális tőke értékéről. Economica, 1., 56-69.

Kong, L. (2000): Culture, economy, policy: trends and developments. Geoforum, 4., 385-390.

KSH [Központi Statisztikai Hivatal] (2008): Tájékoztató a kiemelten támogatott kistérségekról. Központi Statisztikai Hivatal, Budapest http://portal.ksh.hu/pls/ksh/docs/hun/xftp/idoszaki/pdf/kistersegimutato.pdf. (Letöltés: 2011. március 17.)

Nagy E., Boros L. (2010): A kulturális fordulat és hatása a gazdaságföldrajzban. In: Mészáros R., Boros L., Nagy E., Nagy G., Pál V.: A globális gazdaság földrajzi dimenziói. Akadémiai Kiadó, Budapest, 57-84.

Tamás P. (2003): „Kreatív iparok” a közép-európai információs társadalmakban. Magyar Tudomány, 12., 1518-1523.

Throsby, D. (2001): Economics and culture. Cambridge University Press, Cambridge 


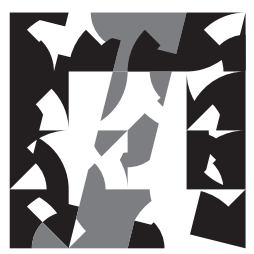

TÉR ÉS TÁRSADALOM | SPACE AND SOCIETY 